\title{
SĘDZIOWIE I GRANICE WŁADZY DEMOKRATYCZNEJ W ŚWIETLE KONSTYTUCJI RP
}

I. Istotą władzy demokratycznej ustanowionej w Konstytucji RP jest ograniczenie tej władzy po to, by chronić prawa jednostki przed zagrożeniami, jakie może stworzyć panowanie większości, zwłaszcza wtedy, kiedy dąży ona do narzucenia innym swoich wartości i przekonań. Ograniczenie to wyraża zarówno zasada podziału i równoważenia władz, jak i zasada demokratycznego państwa prawnego, a przede wszystkim zasada przyrodzonej i niezbywalnej godności człowieka. Tej właśnie zasadzie podporządkowany jest ustrój Rzeczypospolitej oraz interpretacja przepisów dotyczących organizacji aparatu państwowego i sposobu jego działania ${ }^{1}$. W myśl art. 30 Konstytucji RP źródłem wolności i praw człowieka oraz obywatela jest przyrodzona i niezbywalna godność człowieka. Jest ona nienaruszalna, a jej poszanowanie i ochrona jest obowiązkiem władz publicznych. Preambuła do Konstytucji stanowi: „Wszystkich, którzy dla dobra Trzeciej Rzeczypospolitej tę Konstytucję będą stosowali, wzywamy, aby czynili to, dbając o zachowanie przyrodzonej godności człowieka, jego prawa do wolności i obowiązku solidarności z innymi, a poszanowanie tych zasad mieli za niewzruszoną podstawę Rzeczypospolitej Polskiej”. Według Trybunału Konstytucyjnego tych praw, które nawiązując wprost do istoty godności ludzkiej, wyrażają jej kwintesencję i mają charakter praw fundamentalnych, prawodawca nie może „nie tylko kwestionować, ale i ograniczać. Nie są one w zasadniczej swojej treści uzależnione od woli prawodawcy, a tym bardziej od organów stosujaccych prawo, bez względu na to, czy będą to organy administracji publicznej, czy sądy. Stąd określa się je mianem praw przyrodzonych. Z nimi wiąże się niewątpliwie konstytucyjna teza o nienaruszalności godności człowieka. Takie rozumowanie nawiązuje do preambuły i art. 1 Deklaracji Praw Człowieka i Obywatela, z których wynika zasada, że z racji urodzenia się człowiekiem - a nie na podstawie jakichkolwiek innych aktów i czynności prawnych - człowiek jest podmiotem wszystkich praw wynikających z jego człowieczeństwa. W tym znaczeniu godność człowieka nie jest uzależniona od woli ustrojodawcy (prawodawcy)" 2 .

Preambuła nakazuje uczynić godność człowieka „niewzruszoną podstawa” ustroju państwa. W świetle Konstytucji RP zarówno godność człowieka, jak i współistotne jej wartości nie zawdzięczają swego istnienia żadnym władzom i znajdują się poza ich zasięgiem, a więc poza zasięgiem władzy Narodu jako

\footnotetext{
1 Tak L. Garlicki, Polskie prawo konstytucyjne. Zarys wykładu, Warszawa 2017, s. 99.

2 Tak w uzasadnieniu wyroku w sprawie P 12/99.
} 
suwerena ${ }^{3}$. Kluczem do zrozumienia relacji między wolnością a demokracja, a zarazem paradygmatem naszej Konstytucji, jest przyrodzona i niezbywalna godność człowieka, usytuowana w ustawie zasadniczej wyżej od najwyższych władz i najbardziej kwalifikowanych większości ${ }^{4}$.

II. Konstytucja Rzeczypospolitej odzwierciedla założenia demokracji liberalnej ${ }^{5}$, w której wola większości nie stanowi źródła praw człowieka, takiej demokracji, w której prawo człowieka - jak pisał Immanuel Kant - „musi być uważane jako święte, choćby to władzę panująca kosztowało ogromnie dużo

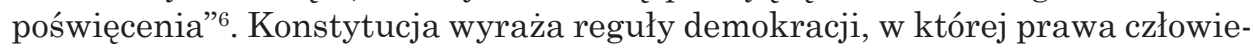
ka kształtują się w dialogu, a wiedza o nich rozwija się stale?

Model ustrojowy państwa TK określił jako demokrację konstytucyjna, a więc taka, w której fundamentem demokratycznego państwa prawnego jest zasada nadrzędności Konstytucji ${ }^{8}$. W państwie tym „parlament nie ma pozycji nadrzędnej nad innymi organami, $\mathrm{z}$ wyjątkiem ściśle określonych wypadków, nie ma także pozycji monopolistycznej w systemie organów państwa. Taka konstrukcja została stworzona m.in. w celu uniknięcia - historycznie znanego - doświadczenia. To doświadczenie to zarówno ryzyko, jak i realne niebezpieczeństwo uproszczonego rozumienia demokracji - głównie, jeśli nie wyłącznie - do wszechwładzy większości parlamentarnej. By uniknać tego niebezpieczeństwa, został stworzony system demokracji konstytucyjnej zawarty w Konstytucji z 1997 r.”.".

Władzy sądowniczej poświęcono w Konstytucji RP - inaczej aniżeli w konstytucjach wielu krajów demokratycznych - osobny rozdział, nie licząc odnoszących się do tej władzy postanowień zawartych w innych rozdziałach ustawy zasadniczej i w jej preambule.

Zgodnie z art. 10 ust. 1 Konstytucji RP ustrój Rzeczypospolitej opiera się na podziale i równowadze władzy ustawodawczej, władzy wykonawczej i władzy sądowniczej.

W myśl art. 173 Konstytucji RP władza sądownicza, którą sprawują Sądy i Trybunały, jest „odrębna i niezależna od innych władz”. Z perspektywy ustawy zasadniczej owa odrębność i niezależność zyskuje swoje znaczenie w kontekście odpowiedzi na pytanie o kształt państwa, a zatem w kontekście reguł demokracji konstytucyjnej ${ }^{10}$, w której godność człowieka i jego prawa wyznaczają granice władzy.

${ }^{3}$ Por. R. Piotrowski, Konstytucja i granice wtadzy suwerena, w: J. Jaskiernia, K. Spryszak, (red.), Dwadzieścia lat obowiazywania Konstytucji RP. Polska myśl konstytucyjna a międzynarodowe standardy demokratyczne, Torun 2017, s. 717.

${ }^{4}$ Ibidem.

${ }^{5}$ Por. M. Tushnet, Advanced Introduction to Comparative Constitutional Law, Cheltenham. Northampton 2014, s. 114 i n.

${ }^{6}$ Tak I. Kant, Zum ewigen Frieden, w: idem, Werke, t. 5, Leipzig 1920, s. 703, cyt. za: M. Szyszkowska, U źródet wspótczesnej filozofii prawa i filozofii człowieka, Warszawa 1972, s. 53.

${ }^{7}$ Por. R. Piotrowski, Konstytucja..., s. 707.

8 Tak TK w uzasadnieniu wyroku w sprawie U 4/06.

${ }^{9}$ Ibidem.

${ }^{10}$ Por. uzasadnienie wyroku TK w sprawie U 4/06. 
Wyodrębnienie władzy sądowniczej jako niezależnej od innych władz jest współistotne zasadzie demokratycznego państwa prawnego oraz zasadzie podziału władz i ich roli w dziedzinie zagwarantowania praw jednostki „przez uniemożliwienie nadużywania władzy przez którykolwiek ze sprawujących ja organów"11. Podstawowy cel regulacji konstytucyjnej, a więc zagwarantowanie wolności i godności jednostki, wymaga podziału i równowagi władz. Podobnie jak pozostałym władzom, preambuła nakazuje władzy sądowniczej uczynić godność człowieka „niewzruszoną podstawą” ustroju państwa. Prawa Rzeczypospolitej powinny być zatem - w świetle preambuły do Konstytucji - interpretowane i stosowane $\mathrm{w}$ myśl zasady in dubio pro dignitate. Ustrojowy sens władzy sądowniczej polega więc na tym, że jest ona strażnikiem godności człowieka, strażnikiem wartości uniwersalnych, ponadczasowych. Zdarza się, że większość parlamentarna ze względu na interesy polityczne zapomina o tych wartościach, albo nie chce o nich pamiętać w procesie ustawodawczym. Władza sądownicza, niezależna od większości parlamentarnej, ma możliwość dokonania korekty ze względu na wartości, które kultura praw człowieka uznaje za nadrzędne w stosunku do jakiejkolwiek władzy ${ }^{12}$, także dysponującej legitymacją wyborczą.

Należy podkreślić, że w świetle orzecznictwa TK zasada podziału władz zakłada, że system organów państwowych powinien zawierać wewnętrzne mechanizmy zapobiegające koncentracji i nadużyciom władzy państwowej, gwarantujace jej sprawowanie zgodnie z wola Narodu i przy poszanowaniu wolności i praw jednostki. Wymóg „rozdzielenia” władz oznacza m.in., że każdej z trzech władz powinny przypadać kompetencje materialnie odpowiadajace ich istocie, a co więcej - każda z tych władz powinna zachowywać pewne minimum kompetencyjne stanowiące o zachowaniu tej istoty. Ustawodawca zaś - kształtując kompetencje poszczególnych organów państwowych - nie może naruszyć owego ,istotnego zakresu” danej władzy ${ }^{13}$.

Według TK zasada podziału władz zakłada szczególny sposób określenia stosunków między władzą sądowniczą a pozostałymi władzami. W stosunkach między władzą ustawodawczą a wykonawczą możliwe są różne formy wzajemnych oddziaływań i współpracy, dopuszcza się również istnienie obszaru, w którym kompetencje organów należących do obu władz „przecinają się” lub „nakładają”. Natomiast relacje między władzą sądowniczą a pozostałymi muszą opierać się na zasadzie „separacji”. Koniecznym elementem zasady podziału władz są niezależność sądów i niezawisłość sędziów ${ }^{14}$.

Jak wskazuje TK: „tylko [...] wobec władzy sądowniczej »rozdzielenie» oznacza zarazem "separację", gdyż do istoty wymiaru sprawiedliwości należy, by sprawowany był on wyłącznie przez sądy, a pozostałe władze nie mogły ingerować w te działania czy w nich uczestniczyć. Wynika to ze szczególne-

11 Tak TK w uzasadnieniu wyroku w sprawie K 11/93.

${ }_{12}$ Por. R. Piotrowski, Władza sqdownicza $w$ Konstytucji RP, „Krajowa Rada Sądownictwa” 2010, nr 1, s. 17 i n.

13 Tak w uzasadnieniu wyroku w sprawie P 16/04.

14 Tak w uzasadnieniu wyroku w sprawie K 8/99. 
go powiązania władzy sądowniczej z ochrona praw jednostki [...]"15. Na tym tle należy rozważyć pogląd Trybunału, w myśl którego wprawdzie rozdzielone władze nie są tym samym niezależnymi od siebie elementami ustroju państwa i każda z nich powinna dysponować takimi instrumentami, które pozwalaja jej powstrzymywać, hamować działania pozostałych, to jednak „mechanizm hamowania i równowagi, zakładający możliwość ingerencji w zakres władzy sądowniczej nie może dotykać niezawisłości sędziowskiej w zakresie sprawowania urzędu, a jakiekolwiek wkraczanie w działanie i organizację władzy sądowniczej, w sferze nie objętej bezwzględną zasadą niezawisłości, może być dokonywane jedynie wyjątkowo i posiadać dostateczne uzasadnienie merytoryczne"16.

Trybunał Konstytucyjny stwierdził ponadto, że odrębność władzy sądowniczej przejawia się w jej szczególnych kompetencjach, polegających na sprawowaniu wymiaru sprawiedliwości. „Sam jednak podział władz nie eliminuje wszelkich powiązań między władzami. Sędziów powołuje Prezydent RP, jako organ władzy wykonawczej, a Minister Sprawiedliwości sprawuje nadzór administracyjny nad sądami powszechnymi. Podstawy działalności sądów stanowią akty parlamentu, a więc władzy ustawodawczej. Wskazane powiązania nie mogą naruszać odrębności władzy sądowniczej, co oznacza, że pozostałym władzom nie można powierzać wymiaru sprawiedliwości”"

Dotychczasowe orzecznictwo TK pozwala zatem uznać, że wkraczanie w działanie i organizację władzy sądowniczej, a więc także nadzór administracyjny Ministra Sprawiedliwości, może być dokonywane wyjątkowo i powinno znajdować uzasadnienie w określonej wartości konstytucyjnej ${ }^{18}$.

W świetle stanowiska doktryny pozycja ustrojowa sądownictwa „w znacznej mierze opiera się na zasadzie separacji lub nawet izolacji władzy sądowniczej” ${ }^{19}$, przy czym należy wykluczyć jakiekolwiek odstępstwa „od zasady podziału władz, które dawałyby władzy ustawodawczej czy władzy wykonawczej prawo do rozstrzygania indywidualnych spraw typu sądowego" ${ }^{20}$.

III. W myśl doktryny „suwerenem jest podmiot, któremu służy władza suwerenna, a więc niezależna $\mathrm{w}$ stosunkach zewnętrznych i najwyższa $\mathrm{w}$ stosunkach wewnętrznych, a poza tym pierwotna i prawnie nieograniczona"21. Wskazano jednak również, że dostrzegane sa „pewne granice, których suweren przekraczać nie powinien, jak chociażby prawa mniejszości politycznej, czy podstawowe prawa i wolności jednostki”22; dla zwolenników koncepcji prawnonaturalnych „prawo natury, bez względu na wskazywane jego źródło,

${ }_{15}$ Tak w uzasadnieniu wyroku w sprawie K 6/94.

${ }_{16}$ Tak w uzasadnieniu wyroku w sprawie K 12/03.

17 Tak w uzasadnieniu wyroku w sprawie K 28/04.

${ }^{18}$ Por. R. Piotrowski, Status ustrojowy sędziego a zakres i charakter zarzadzeń nadzorczych, w: idem (red.), Pozycja ustrojowa sędziego, Warszawa 2015, s. 170 i n.

19 Tak L. Garlicki, Polskie prawo..., s. 79.

${ }^{20}$ Ibidem.

${ }^{21}$ Tak Z. Witkowski (red.), Prawo konstytucyjne, Toruń 2002, s. 64.

22 Tak P. Uziębło, w: A. Łabno (red.), Wielka encyklopedia prawa, t. 6, Warszawa 2016, s. 379 . 
stanowi nieprzekraczalną granice działania jakiegokolwiek suwerena, w tym również suwerena zbiorowego" ${ }^{23}$. Zwraca uwagę uznanie, że „prawo państwa i międzynarodowe jest nie tylko wyrazem (odbiciem) suwerenności, lecz także wartościa, która określa i miarkuje jej granice"24.

W świetle postanowień Konstytucji zwierzchnictwo Narodu jako wartość konstytucyjna nie ma absolutnego charakteru, zwłaszcza wobec zakotwiczonego w pojęciu godności szczególnego statusu praw człowieka ${ }^{25}$.

Obowiąująca Konstytucja odwołuje się do kultury „zakorzenionej w chrześcijańskim dziedzictwie Narodu i ogólnoludzkich wartościach” i pozbawia suwerena władzy nad wartościami, proklamujacc ich transcendentny charakter. Wyklucza to absolutystyczną interpretację pojęcia suwerenności Narodu, skoro wartości podstawowe znajduja się poza jego zasięgiem. Konstytucja sytuuje wartości w roli tradycyjnie przypisywanej suwerenowi ${ }^{26}$.

IV. Zagadnienie roli prawa w ustroju demokratycznym - a więc relacji między państwem prawa, którego zasady wymagają urzeczywistnienia przez władzę sądownicza, niezależna od pozostałych władz, a demokracją rozumianą jako prawo większości parlamentarnej do kształtowania reguł państwa prawnego - jest ściśle związane z wyznaczeniem granic władzy suwerena ${ }^{27}$. Problem ten znajduje odzwierciedlenie we współczesnej literaturze przedmiotu w postaci antynomii dwóch konstytucjonalizmów: prawnego i politycznego. Z punktu widzenia konstytucjonalizmu prawnego władza sądownicza spełnia szczególną rolę w państwie, ponieważ jest najwyższym strażnikiem systemu prawnego regulujacego funkcjonowanie pozostałych władz i obrońca praw jednostki ${ }^{28}$. Z perspektywy konstytucjonalizmu politycznego system prawny jest ograniczonym w czasie układem praw, obowiązków i kompetencji, podlegającym zmianom zależnym od woli większości reprezentującej suwerena ${ }^{29}$. Zasada podziału władz, rozumiana zbyt ortodoksyjnie, może prowadzić do imposybilizmu ograniczającego zdolność działania większości ${ }^{30}$. Nie jest przy tym jasne, dlaczego to właśnie sędziowie, a nie pochodzacy z wyboru politycy maja rozstrzygać spory, w których prawo i polityka pozostają w nierozerwalnym związku.

We współczesnej doktrynie konstytucyjnej Stanów Zjednoczonych wątpliwości te znalazły odzwierciedlenie w postaci - jak dotąd mniejszościowe-

${ }^{23}$ Tak P. Uziębło, w: A. Szmyt (red.), Leksykon prawa konstytucyjnego, Warszawa 2010, s. 585 .

${ }^{24}$ Tak K. Działocha, Uwagi do art. 4, w: L. Garlicki, M. Zubik, Konstytucja Rzeczypospolitej Polskiej. Komentarz, Warszawa 2016, s. 200.

${ }_{25}$ Por. M. Gulczyński, J. Wawrzyniak, Suwerenne prawo narodu do sprawowania władzy zwierzchniej we współczesnych warunkach, w: W. Wołpiuk (red.), Spór o suwerenność, Warszawa 2001, s. 198 i n.

${ }^{26}$ Por. R. Piotrowski: Konstytucja.., s. 702 oraz przedstawiona tam argumentacja, którą wykorzystuję w niniejszym opracowaniu.

27 Ibidem, s. 416.

${ }_{28}$ Por. T.R.S. Allan, The Sovereignty of Law. Freedom, Constitution and Common Law, Oxford 2015, s. 133.

${ }_{29}$ Por. R. Bellamy, Political Constitutionalism, Cambridge 2007, s. 145 i n.

30 Por. przykładowo T.R.S. Allan, op. cit., s. 3. 
go - poglądu, że „Sąd Najwyższy jest naszym sługa, a nie panem; jest sługa, którego powaga i wiedza zasługują na szacunek, ale ostatecznie powinien on podporządkować się naszemu sądowi na temat konstytucji, a nie odwrotnie. Sąd nie jest najwyższym autorytetem kraju w sprawach prawa konstytucyjnego. To my jesteśmy tym autorytetem” ${ }^{31}$. „My” oznacza jednak - w świetle Konstytucji Stanów Zjednoczonych - ustawodawcę funkcjonującego w systemie postrzeganym jako ograniczający podmiotowość obywateli na rzecz korporacji współtworzących ustrój ekonomii wpływu ${ }^{32}$. Swoiste rozczarowanie doktryny rolą sądów w wyznaczaniu granic władzy ustawodawczej odzwierciedla koncepcja „populistycznego konstytucjonalizmu” postulująca kształtowanie prawa konstytucyjnego nie w drodze zmieniającego się orzecznictwa sądowego, ale przez obywateli, „w sposób bardziej bezpośredni i otwarty”33.

W brytyjskiej doktrynie konstytucyjnej problem relacji między sędziami a suwerenem znajduje nieco inne, godne uwagi, rozwiązanie. Polega ono na tym, że konsekwencja szczególnego statusu parlamentu, określanego jako „bezpośredni suweren” pozostaje uznanie konstytucji za „ostatecznego albo normatywnego suwerena" ${ }^{34}$. W literaturze przedmiotu znajduje wyraz pogląd, że suwerenność brytyjskiego parlamentu jest w istocie odzwierciedleniem suwerenności niepisanej konstytucji, z której czerpie on swoje rozległe uprawnienia składające się na supremację legislatywy w granicach rządów prawa ${ }^{35}$; ich urzeczywistnienie jest obowiązkiem sędziów, mających oparcie nie tylko $\mathrm{w}$ woli parlamentu, ale także w zasadach common law, wymagających od sędziów orzekania wedle ich własnej koncepcji zastosowania ideału rządów prawa $\mathrm{w}$ danych okolicznościach. W myśl poglądów części doktryny brytyjska konstytucja common law odzwierciedla kompromis między suwerennością parlamentu a jej ograniczeniami wynikajacymi z zasad rządów prawa. Doświadczenia brytyjskiej koncepcji parlamentaryzmu wskazują na istnienie nierozerwalnego związku suwerenności narodu, parlamentu i konstytucji, związku między suwerennością narodu i suwerennością prawa, a więc niezależnością sądów i niezawisłością sędziów.

V. We współczesnych państwach uważanych za demokratyczne ${ }^{36}$ wzrasta znaczenie władzy sądowniczej, niekiedy z pewną przesadą określane jako „rządy sędziów”" ${ }^{37}$ czy też „jurystokracja” ${ }^{38}$. Do przyczyn wzrostu znaczenia władzy

${ }^{31}$ Tak L.D. Kramer, The People Themselves. Popular Constitutionalism and Judicial Review, Oxford 2004, s. 248.

${ }^{32}$ Tak L. Lessig, Republic, Lost: How Money Corrupts Congress - and a Plan to Stop It, New York 2011, s. 104 i n.

${ }^{33}$ Por. M. Tushnet, Taking the Constitution away from the Courts, Princeton 1999, s. 194.

${ }^{34}$ Tak E. Barker, Political Thought in England, Oxford 1963, s. 212 i n.

${ }^{35}$ Por. T.R.S. Allan, op. cit., s. 133 i n.

${ }^{36} \mathrm{Na}$ temat kryteriów i proponowanego katalogu por. przykładowo A. Lijphart, Democracies, New Haven-London 1984, s. 37 i n.

${ }_{37}$ Por. na ten temat zwłaszcza E. Bruti Liberati, A. Ceretti, A. Giasanti, Governo dei giudici, Milano 1996, s. 7 i n. Por. także R. Piotrowski, O znaczeniu prawa sędziowskiego w polskim systemie państwowym, w: T. Giaro (red.), Rola orzecznictwa w systemie prawa, Warszawa 2016, s. 39 i n.

${ }^{38}$ Por. R. Hirschl, Towards Juristocracy: The Origins and Consequences of the New Constitutionalism, Harvard 2007. 
sądowniczej zalicza się rosnący wpływ sędziów na rozstrzyganie konfliktów między rywalizującymi politykami oraz sporów kompetencyjnych między poszczególnymi segmentami władz publicznych, określany jako jurydyzacja polityki, a także zajmowanie przez sądy stanowiska wobec sporów między wyznawcami przekonań świeckich i religijnych oraz zaspokajanie powszechnej potrzeby potępienia korupcji i niesprawności działania władzy ustawodawczej i wykonawczej ${ }^{39}$. Znaczenie władzy sądowniczej wzrasta jednak także ze względu na kryzys systemu prawa, którego wzrost ten jest następstwem ${ }^{40}$. Regulacje prawne obejmuja kolejne dziedziny życia prywatnego i publicznego, co powoduje stałe poszerzanie zakresu właściwości orzeczniczej związanej z interpretowaniem i stosowaniem przepisów ${ }^{41}$. Inflacja prawa traktowanego jako narzędzie zmiennej polityki społecznej i gospodarczej, wymagającej posługiwania się klauzulami generalnymi, powoduje wzrost znaczenia dyskrecjonalnej władzy sędziów, których rola polega coraz częściej nie tylko na stosowaniu przepisów w odniesieniu do konkretnych przypadków, ale na współtworzeniu reguł, a tym samym współtworzeniu rozwiązań o charakterze politycznym ${ }^{42}$. Niemal każda sprawa publiczna może stać się przedmiotem oddziaływania władzy sądowniczej. Wyroki nie są obojętne dla władzy ustawodawczej i wykonawczej. Apolityczni sędziowie podejmują rozstrzygnięcia, które mogą wpływać na wynik wyborów, a także na finansowanie partii politycznych ze środków publicznych. Władza sądownicza niejednokrotnie ogrywa kluczową rolę w kształtowaniu polityki w państwach demokratycznych, a także w rozwiązywaniu sporów politycznych o zasadniczym znaczeniu ${ }^{43}$.

Wzrost znaczenia władzy sądowniczej stanowi przejaw procesu występującego w państwach demokratycznych od połowy poprzedniego stulecia ${ }^{44}$. Nastapiło wtedy - pod wpływem tragicznych doświadczeń zwiąanych ze zdobyciem władzy przez faszystów - odwrócenie XVIII-wiecznej tendencji do minimalizowania znaczenia władzy sądowniczej w systemie podziału władz ${ }^{45}$,

Do przyczyn wzrostu znaczenia władzy sądowniczej w Polsce należy zjawisko przenikania się kultury prawnej prawa stanowionego i prawa sędziowskiego $^{46}$, związane $\mathrm{z}$ procesem integracji europejskiej ${ }^{47} \mathrm{i}$ konsekwencjami globalizacji, a także $\mathrm{z}$ wielocentrycznością systemu prawa ${ }^{48}$, które zyskuje ponadnarodowy charakter. Integracja europejska powoduje zmiany w syste-

${ }^{39}$ Por. D. Kapiszewski, G. Silverstein, R.A. Kagan, Consequential Courts. Judicial Roles in Global Perspective, Cambridge 2013, s. 35 i n.

${ }^{40}$ Por. E. Łętowska, Prawo w „płynnej nowoczesności”, „Państwo i Prawo” 2014, z. 3, s. 9 i n.

41 Por. C. Guarnieri, P. Pederzoli, C.A. Thomas, The Power of Judges, Oxford 2002, s. 6.

${ }^{42}$ Por. D.L. Horowitz, The Courts and Social Policy, Washington 1977.

${ }^{43}$ Por. D. Smilov, The Judiciary: The Least Dangerous Branch, w: M. Rosenfeld, A. Sajo, The Oxford Handbook of Comparative Constitutional Law, Oxford 2012, s. 869.

${ }_{44}$ Tak C.N. Tate, T. Vallinder (red.), The Global Expansion of Judicial Power, New York 1995, s. 5.

${ }_{45}$ Por. R. Piotrowski, Uwagi o ustrojowym znaczeniu sqdownictwa konstytucyjnego, w: K. Budziło (red.), Księga XXV-lecia Trybunału Konstytucyjnego, Warszawa 2010, s. 335.

46 Por. R.A. Tokarczyk, Komparatystyka prawnicza, Kraków-Lublin 1997, s. 143.

${ }^{47}$ Por. M. Safjan, Bez sędziów nie byłoby Unii Europejskiej, „Rzeczpospolita” z 25 lutego 2009 r.

48 Por. E. Łętowska, Dialog $i$ metody. Interpretacja $w$ multicentrycznym systemie prawa (cz. I i II), „Europejski Przegląd Sądowy” 2008, nr 11 i 12. 
mie źródeł prawa i przeobrażenia pojęcia suwerenności, wysuwające sędziego przed ustawodawcę ${ }^{49}$.

Znaczenie władzy sądowniczej rośnie także dlatego, że coraz mniej jednoznaczne i coraz bardziej skomplikowane prawa wymagaja jej interwencji ${ }^{50}$. Ponadto ustawodawca powierza sądom legitymizowanie poczynań władzy wykonawczej w sferach szczególnie wrażliwych z punktu widzenia praw i wolności jednostki. Sędziowie stają się reprezentantami interesów, które nie są reprezentowane, lub reprezentowanych wadliwie. Wzrost znaczenia przywódców partyjnych oraz lobbistów i biurokracji europejskiej w procesie ustawodawczym powoduje, że apolityczni - a więc niezależni od władz partyjnych - sędziowie stają się depozytariuszami suwerenności Narodu; orzekając, są zdolni reprezentować suwerena niezależnie od partyjnej dyscypliny politycznych interesów determinujących funkcjonowanie ustawodawcy oraz od ograniczajacej demokracje przedstawicielska integracji władzy ustawodawczej i wykonawczej. Ograniczenie roli parlamentu, uwarunkowane wieloma przyczynami, zwiększa znaczenie władzy sądowniczej ${ }^{51}$.

Szczególną rolę w wyznaczaniu granic władzy demokratycznej spełnia w myśl ustawy zasadniczej TK. Przeobrażenia, którym w minionym trzydziestoleciu podlegało pojęcie suwerenności narodowej, związane z jej ograniczeniem przez prawa człowieka sprawiaja, że sądownictwo konstytucyjne stało się strażnikiem granic suwerenności Narodu rozumianej jako wykonywanie władzy opartej na sile wartości, o których mówi preambuła do Konstytucji RP, a zarazem przez te wartości ograniczonych. Tak rozumiane pojęcie suwerenności legitymizuje sądownictwo konstytucyjne, ale zarazem uzależnia tę legitymację od zaangażowania TK w dziedzinie ochrony praw człowieka, skoro miernikiem suwerenności pozostaje respektowanie tych praw. Ostateczność i powszechność obowiązywania jako cechy orzeczeń Trybunału znajdują oparcie w wartościach konstytucyjnych, których ma on bronić przed ustawodawca ${ }^{52}$.

Paradygmatem ustroju demokratycznego staje się prawo do posiadania praw $^{53}$ - bezskuteczne jednak bez udziału sędziów. Znaczenie władzy sądowniczej wzrasta także ze względu na jej rolę w obronie praw zagrożonych przez rozwój nowych technologii informacyjnych ${ }^{54}$, w tym zwłaszcza prawa do prywatności ${ }^{55}$.

\footnotetext{
${ }^{49}$ Por. P.P. Marcisz, Koncepcja tworzenia prawa przez Trybunat Sprawiedliwości Unii Europejskiej, Warszawa 2015, s. 239 i n. Por. także Z. Brodecki (red.), op. cit., s. 46.

${ }^{50}$ Por. M. Krajewski, Znaczenie zwrotów niedookreślonych i nieostrych dla prawotwórczej wyktadni dokonywanej przez sqdy administracyjne, w: J.P. Tarno, T. Bąkowski (red.), Prawotwórstwo sqdów administracyjnych, Warszawa 2015, s. 170 i n.

${ }^{51}$ Por. R. Piotrowski, O znaczeniu..., s. 42.

${ }^{52}$ Por. idem, Trybunat Konstytucyjny na straży wolnych wyborów i podstaw demokracji, Warszawa 2017 [w druku].

${ }^{53}$ Por. S. Rodota, Il diritto di avere diritti, Roma-Bari 2012, s. 41 i n. Por. R. Piotrowski, O znaczeniu..., s. 44.

${ }^{54}$ Por. M. Zubik, Nowe technologie jako wyzwanie i zagrożenie dla prawa, statusu jednostki i państwa, w: P. Girdwoyń (red.), Prawo wobec nowoczesnych technologii, Warszawa 2008, s. 37 i n.

${ }^{55}$ Por. R. Piotrowski, Prawa człowieka wobec globalizacji, w: M. Zubik (red.), XV lat obowiazywania Konstytucji z 1997 r., Warszawa 2012, s. 69 i n.
} 
W demokratycznym państwie prawnym, w którym władza większości jest ograniczona przez prawa przysługujące mniejszości, co znajduje odzwierciedlenie w formule demokracji konstytucyjnej, źródłem legitymizacji władzy sadowniczej nie jest wynik wyborów, w szczególności parlamentarnych, ale zdolność orzekania niezależnie od woli i interesów partii politycznych. Kontroluja one władzę ustawodawcza, niekiedy także zależne od większości parlamentarnej sądy konstytucyjne. Kontrolują również władzę wykonawcza. Obywatel jest więc zasadniczo uzależniony od polityków, nawet jeśli nie udziela im poparcia wyborczego. Jedynie władza sądownicza może od tej zależności bronić, jeżeli sędziowie są niezawiśli, a sądy niezależne.

Sędziowie nie pochodzą wprawdzie z wyborów, mających taki charakter, jak wybory parlamentarne czy prezydenckie, ale wydaja wyroki w imieniu Rzeczypospolitej, która - jak stanowi Konstytucja - jest dobrem wspólnym wszystkich obywateli. W doktrynie znalazł wyraz pogląd, w myśl którego „sądy i trybunały wydają wyroki w imieniu Rzeczypospolitej Polskiej, której władza zwierzchnia należy do Narodu (art. 4 i art. 174 Konstytucji). Tym samym sądy i sędziowie również posiadają legitymację wywodzoną z woli Narodu, niepochodząca natomiast $\mathrm{z}$ bezpośrednich wyborów" ${ }^{56}$. Z tej perspektywy sa oni także przedstawicielami suwerena, zwłaszcza jeżeli uznajemy, że w demokratycznym państwie prawnym suwerenem sa w istocie prawa odzwierciedlające suwerenność wartości, które ograniczają władzę Narodu ze względu na prawa człowieka w rezultacie zmiany obejmującej „pojęcie suwerenności jako władzy najwyższej i nieograniczonej, zarówno w stosunkach wewnętrznych państwa, jak i jego stosunkach zewnętrznych" ${ }^{\text {"7 }}$. Zdaniem TK w demokratycznym państwie prawnym dokonuje się zastapienie „zasady suwerenności monarchy zasada zwierzchnictwa narodu, ograniczonego przez prawa człowieka, mające swe źródło w nienaruszalnej godności ludzkiej" ${ }^{58}$. Suwerenem są zatem wartości znajdujące wyraz w prawie ${ }^{59}$. Sędziowie, podlegając Konstytucji, sa legitymowani do czuwania nad respektowaniem tych wartości i do strzeżenia konstytucyjnie wyznaczonych granic władzy suwerena. Powierzone sądom powszechnym sprawowanie wymiaru sprawiedliwości oraz należące do Trybunału Konstytucyjnego orzekanie o zgodności prawa z Konstytucją czyni te sądy oraz Trybunał depozytariuszami prawa do rozstrzygania sporów stanowiącego atrybut władzy suwerennej ${ }^{60}$. Obowiązująca ustawa zasadnicza, przyznając zwierzchnią władzę Narodowi, wymaga uznania za ustrojową przesłanka owego zwierzchnictwa sprawowanie go na zasadach i w formach określonych w Konstytucji. Oznacza to w szczególności konstytucyjną legitymację władzy sądowniczej do ograniczania - ze względu na postanowienia Konstytucji jako najwyższego prawa - pozostałych władz, jak też suwerena sprawującego swą władzę bezpośrednio.

${ }_{56}$ Por. A. Machnikowska, O niezależności sq̨dów i niezawisłości sędziów w trudnych czasach. Wymiar sprawiedliwości w pułapce sprawności, Warszawa 2018, s. 58.

${ }_{57}$ Tak TK w uzasadnieniu wyroku w sprawie K 32/09.

58 Ibidem.

59 Por. R. Piotrowski, Konstytucja..., s. 712.

${ }^{60}$ Por. D. Smilov, op. cit., s. 869. 
VI. Odpowiedź na pytanie o rolę sędziów w ustalaniu granic władzy demokratycznej wymaga zgodnej z Konstytucją wykładni jej postanowień. Tego rodzaju wykładnia, która można określić jako prokonstytucyjna, powinna respektować tożsamość aksjologiczną Konstytucji, znajdująca wyraz w uznaniu w jej preambule wartości za niewzruszona podstawę państwa. Chodzi zatem o wykładnię holistyczna, która nie ustala znaczenia postanowień Konstytucji w oderwaniu od ich wzajemnego związku. Skoro w myśl jej art. 8 ust. 1 Konstytucja jest najwyższym prawem, to wattpliwości interpretacyjne należy rozstrzygać na rzecz respektowania podstawowych wartości i zasad konstytucyjnych wyznaczajacych reguły racjonalności ustrojowej. Pozwoli to na uniknięcie paradoksalnych rezultatów wykładni, związanych choćby z uznaniem, że uchylenie ustawowej regulacji organizacji TK oraz trybu postępowania przed TK (art. 197 Konstytucji RP) wykluczyłoby możliwość wypełniania przez Trybunał jego funkcji wymienionych w ustawie zasadniczej. Podobnie antykonstytucyjny charakter miałaby wykładnia językowa przepisu Konstytucji, w myśl którego w skład Krajowej Rady Sądownictwa wchodzi „piętnastu członków wybranych spośród sędziów" (art. 187 ust. 2 pkt 2 Konstytucji RP), jeśli rezultatem tej wykładni byłoby uznanie, że owych sędziów nie wybierają sędziowie. Oznaczałoby to, że konstruując normę konstytucyjną ignorujemy sprecyzowane w ustawie zasadniczej zadania tej Rady, do których należy strzeżenie niezależności sądów i niezawisłości sędziów (art. 186 ust. 1), a ponadto pomijamy przepis art. 173 Konstytucji, zgodnie z którym sądy są władza „niezależną i odrębną od innych władz”.

Wykładnia, pozwalająca w zgodzie z Konstytucją określić rolę sędziów w wyznaczaniu granic demokratycznej władzy, powinna sprzyjać urzeczywistnieniu w największym możliwym stopniu nie tylko postanowień ustawy zasadniczej wobec brzmienia jej art. 8 ust. 1, ale także urzeczywistnieniu wartości znajdujacych wyraz w prawie międzynarodowym. W myśl art. 9 Konstytucji Rzeczpospolita przestrzega wiążącego ją prawa międzynarodowego. Chodzi zatem o wartości i zasady mające oparcie w szczególności w Powszechnej deklaracji praw człowieka, Karcie Narodów Zjednoczonych, europejskiej Konwencji o ochronie praw człowieka i podstawowych wolności, Traktacie o Unii Europejskiej, Karcie praw podstawowych Unii Europejskiej. Wartości te, których strażnikami sa sędziowie z mocy art. 9 i 91 Konstytucji RP, ograniczają władzę zwierzchnia suwerena w takim zakresie, w jakim są tożsame z wartościami i zasadami Konstytucji RP.

W szczególności przepis art. 91 ust. 3 Konstytucji stanowi, że jeżeli wynika to z ratyfikowanej przez Rzeczpospolitą umowy konstytuującej organizację międzynarodowa, prawo przez nią stanowione jest stosowane bezpośrednio, mając pierwszeństwo w przypadku kolizji z ustawami. A zatem sąd „ma obowiązek rozstrzygnięcia sprawy na podstawie przepisu Unii i pominięcia kolidującego z nim przepisu prawa polskiego"61. Tym samym sąd powszechny lub administracyjny określa granice władzy ustawodawczej w ten sposób, że w konkretnej

${ }^{61}$ Tak L. Garlicki, Polskie prawo..., s. 506. 
sprawie odmawia zastosowania prawa ${ }^{62}$, które jest wyrazem woli demokratycznie legitymowanych przedstawicieli suwerena.

Zasadniczą konsekwencją integracji europejskiej pozostaje uznanie szczególnej roli niezależnych i niezawisłych sądów w demokratycznym państwie prawnym, bez których byłoby możliwe skoncentrowanie władzy ustawodawczej i wykonawczej. Polityczna jednorodność tych władz mogłaby stanowić przesłankę funkcjonowania swoistej tyranii większości, zagrażającej Unii Europejskiej rozumianej jako wspólnota wartości. Z Traktatu o Unii Europejskiej wynika doniosła rola sądów w dziedzinie ochrony Konstytucji RP przed stosowaniem przepisów ustawowych sprzecznych z prawami podstawowymi gwarantowanymi przez tę Konstytucję.

Obecny model wykładni Konstytucji zapewnia systemową przewagę wykładni dokonywanej przez sędziów Trybunału Konstytucyjnego i nie wyklucza wykładni dokonywanej przez Sąd Najwyższy i sądy powszechne. Dyskrecjonalną w istocie władzę sędziów, określaną w doktrynie jako przejaw „niewątpliwie jednej z najsilniejszych postaci władzy w całym systemie prawnym”63, co znajduje potwierdzenie zwłaszcza w przypadku TK, można pogodzić z art. 8 ust. 1 Konstytucji, według którego jest ona najwyższym prawem, jedynie w warunkach rzeczywistej niezależności sądów i niezawisłości sędziów. Wymaga to jednak zachowania wysokiego poziomu kultury konstytucyjnej, zwłaszcza w procesie powoływania sędziów. W przeciwnym razie wykładnia Konstytucji sprzyjać może prymatowi polityki nad Konstytucją. Tego rodzaju „polityczny konstytucjonalizm” trudno pogodzić z zasadami demokracji konstytucyjnej znajdującymi wyraz w Konstytucji RP, w tym zwłaszcza z zasada podziału władz. Celowe dokonywanie antykonstytucyjnej wykładni Konstytucji jest $\mathrm{w}$ istocie swego rodzaju deliktem konstytucyjnym, niepowodujacym jednak pociagnięcia do odpowiedzialności konstytucyjnej. Odpowiedzialność za „przewrotne tłomaczenie Konstytucyi” przewidywała Deklaracja Stanów Zgromadzonych z 1791 r., która stanowiła, że ten, kto dokonuje tego rodzaju wykładni „najsurowszymi karami natychmiast przez sąd sejmowy ukarany będzie" "64. Nie wydaje się jednak możliwe - z perspektywy poszanowania zasad niezależności sądów i niezawisłości sędziów - egzekwowanie odpowiedzialności sędziów za wykładnię sprzeczną z wyobrażeniami o Konstytucji ekspertów, polityków czy też opinii publicznej.

Trybunał Konstytucyjny ustalający taką wykładnię Konstytucji, która jest zgodna z poglądami większości parlamentarnej, może być zagrożeniem dla ustawy zasadniczej, zwłaszcza jeżeli legitymizuje w drodze wykładni zmiany Konstytucji przeprowadzane za pomocą ustaw zwykłych. Jednakże TK, który nie zgadza się z większościa parlamentarna, lub - jak wskazują doświadczenia ${ }^{65}$ ostatnich lat - jest posądzany o to, że mógłby stać się rzecznikiem opozycji par-

${ }^{62}$ Por. A.B. Capik, A. Łazowski, Uwagi do art. 91, w: M. Safjan, L. Bosek, Konstytucja RP. Komentarz, t. 2, Warszawa 2016, s. 162 i n.

63 Tak M. Gutowski, P. Kardas, Wykładnia i stosowanie prawa w procesie opartym na Konstytucji, Warszawa 2017, s. 4.

${ }_{64}$ Por. Deklaracyja Stanów Zgromadzonych, w: Konstytucja 3 Maja, Warszawa 1981, s. 106 i n.

65 Por. P. Radziewicz, P. Tuleja (red.), Konstytucyjny spór o granice zmian organizacji i zasad działania Trybunału Konstytucyjnego, Warszawa 2017. 
lamentarnej, zostaje - wbrew Konstytucji - pozbawiony właściwości niepokojących większość parlamentarna. W konsekwencji następuje groźne dla ustroju konstytucyjnego osłabienie pewności prawa zasadniczego.

W demokracji konstytucyjnej, której reguły odzwierciedla obowiązująca ustawa zasadnicza, wykładnia Konstytucji znajduje oparcie w dialogu społecznym jako podstawie konsensusu legitymizującego państwo i prawo. Wymaga to jednak kształtowania kultury konstytucyjnej opartej na współdziałaniu respektującym zasadę dobra wspólnego, która nie pozwala na dyskryminowanie mniejszości i wykluczenie przeciwników politycznych. Władza demokratyczna odrzucająca zasadę, w myśl której państwo jest dobrem wspólnym jego obywateli, traci swoje właściwości. Partie polityczne, których celem jest obalenie Konstytucji w drodze zastępowania w prawie obowiązującym dobra wspólnego dobrem większości przez te partie reprezentowanej i w drodze podporządkowania sędziów politykom, uchybiają konstytucyjnemu obowiązkowi działania metodami demokratycznymi. Pozbawienie władzy sądowniczej możliwości wyznaczania granic władzy demokratycznej prowadzi do przekazania politykom występującym w imieniu suwerena pełni władzy nad suwerenem ze wszystkimi tego ustrojowymi konsekwencjami, odnoszaccymi się także do tożsamości europejskiej państwa.

Europa to przecież nie tylko pluralistyczna cywilizacja ${ }^{66}$, ukształtowana w długim procesie rozwoju i jej nazwa, spełniająca rolę określenia „świat chrześcijański” ${ }^{67}$. Europa - w świetle aksjologii integracji europejskiej ${ }^{68}$ - jest $\mathrm{w}$ istocie związana $\mathrm{z}$ ową cywilizacją swego rodzaju wartościa, wyrażająca afirmację praw człowieka, afirmację wolności, która nie ignoruje godności i dobra wspólnego, a jednocześnie odzwierciedla dążenie do urzeczywistnienia tych wartości ${ }^{69}$. Potwierdza to Traktat o Unii Europejskiej, w myśl którego „Unia opiera się na wartościach poszanowania godności osoby ludzkiej, wolności, demokracji, równości, państwa prawnego, jak również poszanowania praw człowieka, w tym praw osób należących do mniejszości” (art. 2). Preambuła Traktatu wskazuje, że strony tej umowy są inspirowane „kulturowym, religijnym i humanistycznym dziedzictwem Europy, z którego wynikaja powszechne wartości, stanowiące nienaruszalne i niezbywalne prawa człowieka, jak również wolność, demokracja, równość oraz państwo prawne”. Według preambuły państwa członkowskie podkreślają swoje „przywiązanie do zasad wolności, demokracji, poszanowania praw człowieka i podstawowych wolności oraz państwa prawnego". Oznacza to, że państwa członkowskie opieraja swoje konstytucje na tych właśnie wartościach ${ }^{70}$. Zarazem Traktat uznaje, że

${ }^{66}$ Por. H. Kissinger, World Order. Reflections on the Character of Nations and the Course of History, London 2014, s. 11 i n.

${ }^{67}$ Tak N. Davies, Europa, Kraków 1998, s. 31. Por. także A. Pagden (red.), The Idea of Europe, Cambridge 2002, s. 33 i n.

${ }_{68}$ Por. Z. Brodecki, Idee - wartości (duch Traktatu) i sztuka rzqdzenia, w: idem (red.), Europa sędziów, Warszawa 2007, s. 39 i n.

${ }^{69}$ Por. R. Piotrowski, Europa i granice wtadzy ustrojodawczej, w: T. Giaro (red.), Prawne problemy i wyzwania Unii Europejskiej, Warszawa 2018 [w druku].

${ }^{70}$ Por. L. Garlicki, Wprowadzenie, w: W. Staśkiewicz (red.), Konstytucje państw Unii Europejskiej, Warszawa 2011, s. 8 i n. 
„Prawa podstawowe, zagwarantowane w europejskiej Konwencji o ochronie praw człowieka i podstawowych wolności oraz wynikające z tradycji konstytucyjnych wspólnych Państwom Członkowskim, stanowią część prawa Unii jako zasady ogólne prawa" (art. 6 ust. 3). Europejski ład prawny cechuje zatem pluralizm konstytucyjny, oparty na fundamencie poszanowania „tożsamości narodowej” państw członkowskich, „nierozerwalnie związanej z ich podstawowymi strukturami politycznymi i konstytucyjnymi” (art. 4 ust. 2).

Granice władzy ustrojodawczej wyznaczone sa przez uniwersalne wartości konstytucyjne, określające - niezależnie od kontrowersji dotyczących ich interpretacji $^{71}$ - zarówno europejska tożsamość konstytucyjną, jak i tożsamość konstytucyjną państw europejskich. Ograniczenie państw członkowskich Unii Europejskiej w kształtowaniu treści własnych konstytucji nie ma bezwzględnego charakteru. Istotnym ograniczeniem władzy ustrojodawczej tych państw jest, poza uwarunkowaniami politycznymi i gospodarczymi oraz konsekwencjami globalizacji, ich własna tradycja konstytucyjna, jak również wartości kultury prawnej wyznaczające jej europejską tożsamość.

VII. Istnienie niezależnego i niezawisłego sądownictwa prowadzi z jednej strony do odrzucenia w koncepcji demokracji założenia o nieograniczonym zakresie woli suwerena jako podmiotu władztwa państwowego, z drugiej zaś do uznania za wyznacznik demokracji tych tylko przejawów woli większości, które mają legitymację konstytucyjna, a zatem zgodne są z wersją kultury praw człowieka zapisana w ustawie zasadniczej i w czasie orzekania znajdującą akceptację sędziów.

Konstytucje współczesnych państw demokratycznych w różny sposób regulują relacje między władzą sądowniczą a pozostałymi władzami. Przeciwieństwem rozwiązania odzwierciedlającego zasadę separacji władzy sadowniczej, przyjętego w Konstytucji RP i zakładającego odpowiedzialność sędziów przed sędziami, jest powoływanie sędziów w wyborach powszechnych, co ma służyć urzeczywistnieniu ich odpowiedzialności przed obywatelami ${ }^{72}$. Dążenie do nadania politycznego charakteru odpowiedzialności sędziów znajduje wyraz $\mathrm{w}$ przyznawaniu ministrom sprawiedliwości znaczącej roli w powoływaniu sędziów. W doktrynie wskazano, że problem równowagi między odpowiedzialnością sędziów a ich niezawisłością może być rozmaicie rozwiązywany w państwie demokratycznym ${ }^{73}$. Niezwykle istotne jest jednak to, aby konkretne rozwiązanie odpowiadało obowiązującej konstytucji. Ustrojowe usytuowanie władzy sądowniczej, nierozerwalnie związane ze zrównoważeniem roli polityków i sędziów w procesie powoływania na urząd sędziego, jest czynnikiem decydującym o jej legitymizacji w państwie, którego ustawa zasadnicza odzwierciedla reguły określane mianem liberalnego konstytucjonalizmu ${ }^{74}$.

${ }^{71}$ Por. D. Davis, A. Richter, Ch. Saunders, An Inquiry into the Existence of Global Values, Oxford-Portland 2015, s. 469 i n.

${ }^{72}$ Por. D. Smilov, op. cit., s. 861

${ }^{73}$ Ibidem.

${ }^{74}$ Por. M. Tushnet, Advanced Introduction..., s. 114 i n. 
Zasady podziału władz i demokratycznego państwa prawnego wykluczają uznanie, że granice władzy sądowniczej wyznaczone są nie przez postanowienia konstytucji, ale przez reguły o charakterze politycznym, zmieniające konstytucję bez zmiany jej postanowień, jedynie w drodze zmiany praktyki odzwierciedlonej w ustawodawstwie. Dążenia władzy wykonawczej do utrzymania i powiększania wpływu na władzę sądownicza, co destabilizuje tę władzę, zagrażaja konstytucyjnemu statusowi sędziów, a przez to także prawom i wolnościom jednostki.

Odrębność i niezależność władzy sądowniczej ma z tego punktu widzenia istotny sens ustrojowy - chodzi przecież o sprawowanie ważnej w ustroju demokratycznym funkcji arbitra w sporach między zwycięską większością i mniejszościami, o ochronę praw mniejszości i ustalenie granic, których mniejszość nie powinna przekraczać, zachowując swoją tożsamość i godząc $\mathrm{w}$ ten sposób w większościowe poczucie słuszności. Sprawowanie tej funkcji wymaga sądu odseparowanego od władzy większości na tyle skutecznie, by mógł się jej przeciwstawić, zwłaszcza wydając wyroki trudne do zaakceptowania przez wyborców, od których woli zależy los rządu. Tego rodzaju oddzielenie może okazać się szczególnie istotne zwłaszcza wtedy, kiedy większość nie opowiada się po stronie praw mniejszości, czy też praw człowieka, co może być nawet dogodne dla sprawujących władzę wykonawczą ${ }^{75}$. Afirmacja praw mniejszości w orzecznictwie sądowym może odzwierciedlać wyobrażenia sędziów o dobrym państwie i dobrym społeczeństwie, które nie są zgodne z wyobrażeniami większości; może ona jednak spowodować wiążąca sędziów zmianę ustawy zasadniczej. Konstytucja RP nie absolutyzuje roli większości w procesie tworzenia prawa, stanowiąc, że jego podstawa jest dialog. Orzecznictwo sądowe odzwierciedlające inny niż większościowy punkt widzenia może sprzyjać owemu dialogowi.

Konstytucyjnie ustanowiona niezależność i odrębność władzy sądowniczej pozwala przezwyciężyć sprzeczność między sprawowaniem władzy zwierzchniej przez Naród a gwarancjami praw i wolności jednostki mających swoje źródło nie w woli władzy, ale w przyrodzonej i niezbywalnej godności człowieka. Jednak władza sądownicza nie zastapi Narodu i jego przedstawicieli w roli strażników praw i wolności, których istnienie zależy nie tylko od niezawisłych i niezależnych sądów, ale przede wszystkim od społecznego poparcia dla owych praw, którego brak powoduje atrofię ustroju demokratycznego i przekształca władzę sądowniczą w jej własne przeciwieństwo w konsekwencji utraty niezależności i niezawisłości.

dr hab. Ryszard Piotrowski

Profesor Uniwersytetu Warszawskiego

r.piotrowski@wpia.edu.pl

${ }^{75}$ Por. R. Piotrowski, Zagadnienie legitymizacji władzy sqdowniczej w demokratycznym państwie prawnym, w: A. Machnikowska (red.), Legitymizacja władzy sqdowniczej, Gdańsk 2016, s. 18 i n. 


\section{JUDGES AND GUARANTEES OF DEMOCRATIC POWER IN CONSTITUTIONAL COURTS}

\section{Sum mary}

The essence of the democratic power established in the Constitution of the Republic of Poland is to limit this power in order to protect the rights of the individual against threats that may be posed by the rule of the majority, especially when this majority seeks to impose its values and beliefs on others. This limitation is expressed both by the principle of the separation and balance of powers and by the principle of a democratic rule of law, and above all by the principle of the inherent and inalienable dignity of man. In the light of the Constitution, the supremacy of the nation as a constitutional value is not of an absolute nature, especially in the context of the special status of human rights which is anchored in the concept of dignity. The current Basic Law, granting the supreme authority to the Polish nation, requires that the authority of that supremacy be exercised in compliance with the principles and in forms set forth in the Constitution. This means in particular, the constitutional legitimacy of the judiciary to restrict, pursuant to the provisions of the Constitution as the supreme law, the powers of other authorities, as well as the authority (sovereign) exercising its power directly. The existence of independent judiciary leads, on the one hand, to the rejection in the conception of a democratic state, of the assumption of an unlimited scope of power of the governing authority, and on the other hand, to the recognition as a determinant of democracy of only those manifestations of the will of the majority, which have a constitutional legitimacy and are therefore in line with the version of the culture of human rights as enshrined in the Basic Law and which are accepted by judges at the time of the ruling. 
